\title{
Reproduction performance, morphometric and structure population of Kuntu buffalo (Bubalis bubalis Merr) in Kampar District, Riau, Indonesia
}

\author{
YENDRALIZA $^{1, \boldsymbol{\nu}}$, MUHAMAD RODIALLAH ${ }^{\mathbf{1}}$, ZUMARNI $^{1}$, ELFAWATI $^{1}$, HIDAYATI $^{1}$, KUSNADI $^{\mathbf{2}}$ \\ ${ }^{1}$ Faculty of Agriculture and Animal Science, Universitas Islam Negeri Sultan Syarif Kasim Riau. Jl. HR. Soebrantas Km 15 No. 155 , Simpang Baru \\ Panam, Pekanbaru 28293, Riau, Indonesia. Tel.: +62-761-562223, `email: yendraliza@uin-suska.ac.id \\ ${ }^{2}$ Faculty of Teacher Training and Education, Universitas Islam Negeri Sultan Syarif Kasim Riau. Jl. HR. Soebrantas Km 15 No. 155 , Simpang Baru \\ Panam, Pekanbaru 28293, Riau, Indonesia
}

Manuscript received: 17 March 2021. Revision accepted: 26 May 2021.

\begin{abstract}
Yendraliza, Rodiallah M, Zumarni, Elfawati, Hidayati, Kusnadi. 2021. Reproduction performance, morphometric and structure population of Kuntu buffalo (Bubalis bubalis Merr) in Kampar District, Riau, Indonesia. Biodiversitas 22: 3370-3377. Kuntu buffalo is one of the germplasm of Riau Province. This study aimed was to determine reproduction performance, potential output, population dynamics, and morphometrics of Kuntu buffalo in Kampar Kiri, Indonesia. The research was conducted in July-October 2019 with materials used in the study were 2.746 buffalo and 1.117 buffalo breeders. The research method used was a survey. The respondents from five locations were determined using a purposive sampling technique. The age at first mating of buffalo $42 \pm 0.7$ months, the S/C $2.6 \pm 1.5$ times, calving interval $15.3 \pm 2.3$ months and calving rate $55.59 \%$. The reproductive efficiency of Kuntu buffalo $96.22 \%$, a natural increase of $55.59 \%$, the net replacements rates (male and female) were $289.60 \%$ and $446.59 \%$, respectively and potential output of $39.24 \%$ was obtained. The population dynamics of the Kuntu buffalo from 2014 to 2019 experienced a growth of $48 \%$ with prediction of the population in 2023 is 7.277 heads. The average body size of male and female Kuntu buffalo is small. The conclusion of Kuntu buffalo reproduction is still efficient with the availability of substitute livestock exceeding the need of livestock and the natural increase of Kuntu buffalo population is very high.
\end{abstract}

Keywords: Kuntu buffalo, morphometrics, natural increase, net replacement stock, reproduction

\section{INTRODUCTION}

Buffalo kuntu is one of the germplasm of Riau Province through the Decree of the Minister of Agriculture of the Republic of Indonesia No. 1053/kpts/SR.120/10/2014. Kampar District is one of Kuntu buffalo development area with a total population of 15.938 heads. The largest population of Kuntu buffalo is in Kampar Kiri District of 4.870 heads (Department of Animal Husbandry and Animal Health of Riau Province 2019). Data center statistics of Riau Province stated that the increase in buffalo population from year to year is only $0.13 \%$. Meanwhile, $8 \%$ of animal protein availability in Riau comes from Kuntu buffalo. The characteristics of Kuntu buffalo is that it is resistant to disease, can adapt to climatic conditions and feed roughing. In addition, breeding Kuntu buffalo is prestige in Kampar society and maintained for generations in the community. Related to the potential owned by Kuntu buffalo, efforts are needed to maintain purity and sustainability in accordance with the agroecosystems and preferences of local farmers. The availability of livestock seedlings both in number and quality is a means to support the development of local livestock, therefore in order to maintain the stability of the Kuntu buffalo population needs to evaluate the development of Kuntu buffalo (Rohyan et al. 2016). Reproductive aspects are one of the determining factors in the evaluation of livestock development (Akma et al. 2016). Evaluation of population dynamics to control a population is important be conducted. The performance of reproductive will be influence growth of production. Scientific information morphometric characteristics required for the conservation of Kuntu buffalo. The composition of life in the population structure will determine the reproductive efficiency, needs of surrogate livestock and is useful for estimating the population in the years to come (Kathiravan et al. 2011). Some research on reproductive efficiency and population structure has been conducted on local Indonesian cattle are Bali cattle (Ciptadi et al. 2014), Pesisir cattle (Putra et al. 2015), Ongole grade (Rohyan et al. 2016), Pasundan cattle (Said et al. 2017), Kuantan cattle (Yendraliza et al. 2020).

The research on reproductive efficiency and composition of the Kuntu buffalo population not be conducted yet. In relation to the development of the Kuntu buffalo, especially in Kampar, analysis of population dynamics and potential yield of Kuntu buffalo Kampar District of Riau Province is important to do. The purpose of the research was to elucidate the reproductive characteristics, dynamics population and morphometrics of Kuntu buffalo in Kampar Districts of Riau Province, Indonesia. 


\section{MATERIALS AND METHODS}

\section{Study area}

The research was conducted in January to March in Kampar Kiri Sub-district, Kampar District, Riau Province, Indonesia. The selected villages are the largest number of buffalo-cows, namely Lipat Kain Selatan, Teluk Paman, Kuntu and Domo. The location of the study is located between $0^{\circ} 00^{\prime} 40^{\prime \prime}-00^{\circ} 27^{\prime} 00^{\prime \prime} \mathrm{N}$ and $100^{\circ} 28^{\prime} 30^{\prime \prime}-100^{\circ} 14^{\prime} 30^{\prime \prime} \mathrm{E}$ (Figure 1). Temperatures range from $27-33^{\circ} \mathrm{C}$ with an average humidity of $78-94 \%$. The average rainfall is around $283 \mathrm{~mm}$ per year.

\section{Materials}

The total cattle used are 2.746 buffalo consisting of 251 male buffalo and 1.189 female buffalo and a total of 1.117 breeders. Secondary data is taken from the Kampar Agriculture and Livestock department covering the area and population of livestock.

\section{Methods}

The place of research is determined by the largest buffalo population. The location selected was 4 out of 20 districts in Kampar District. The respondents are selected by the criteria that they have had buffalo that have twice given birth and have the highest number of livestock. Data collection was carried out by survey. Reproduction and population structure data were collected through interviews with selected respondents using a questionnaire. For morphometric data, direct field measurements are carried out. Buffalo measurements are performed on female buffaloes that have already given birth and adult male buffaloes. The variable measured is:

\section{Reproductive efficiency (RE)}

Reproductive efficiency (RE) is calculated by formula (Chamdi 2005):

$$
R E=\frac{(\text { Calving interval })(\text { number of calves })}{\text { (age of first calring }- \text { age first time mating })+(\text { calving interval }- \text { gestation periode })}
$$

Where: RE: reproductive efficiency.

\section{Morphometric}

Morphometric measurements of buffalo consist of; (i) The length of the body measured from the distance of a straight line from the point of the shoulder of the posterior to the pin bone. (ii) The height of the shoulders measured from the highest distance of withers to the ground level. (iii) The height of the hips is measured from the highest distance of the hips perpendicular to the ground. (iv) Chest circumference is measured circularly just behind fourth rib (Budiarto and Ciptadi 2018).

\section{Natural increase (NI)}

Natural increase measured according to Samberi et al. (2010).

$\mathrm{NI}=$ calving rate based on population $(\%)$-mortality $(\%)$.

Calving rate based on population $=\frac{\text { number of calves }}{\text { number of population }} \times 100 \%$

$$
\text { Mortality }(\%)=\frac{\text { number of death buffalo }}{\text { number of population }} \times 100 \%
$$

\section{Net replacement rate (NRR)}

Obtained from the comparison of the number of young buffalo replacement candidates divided by the needs of replacement buffalo per year multiplied by $100 \%$. The NRR value is used to determine whether the number of livestock births can cover the need for replacement livestock in order to keep the population constant.
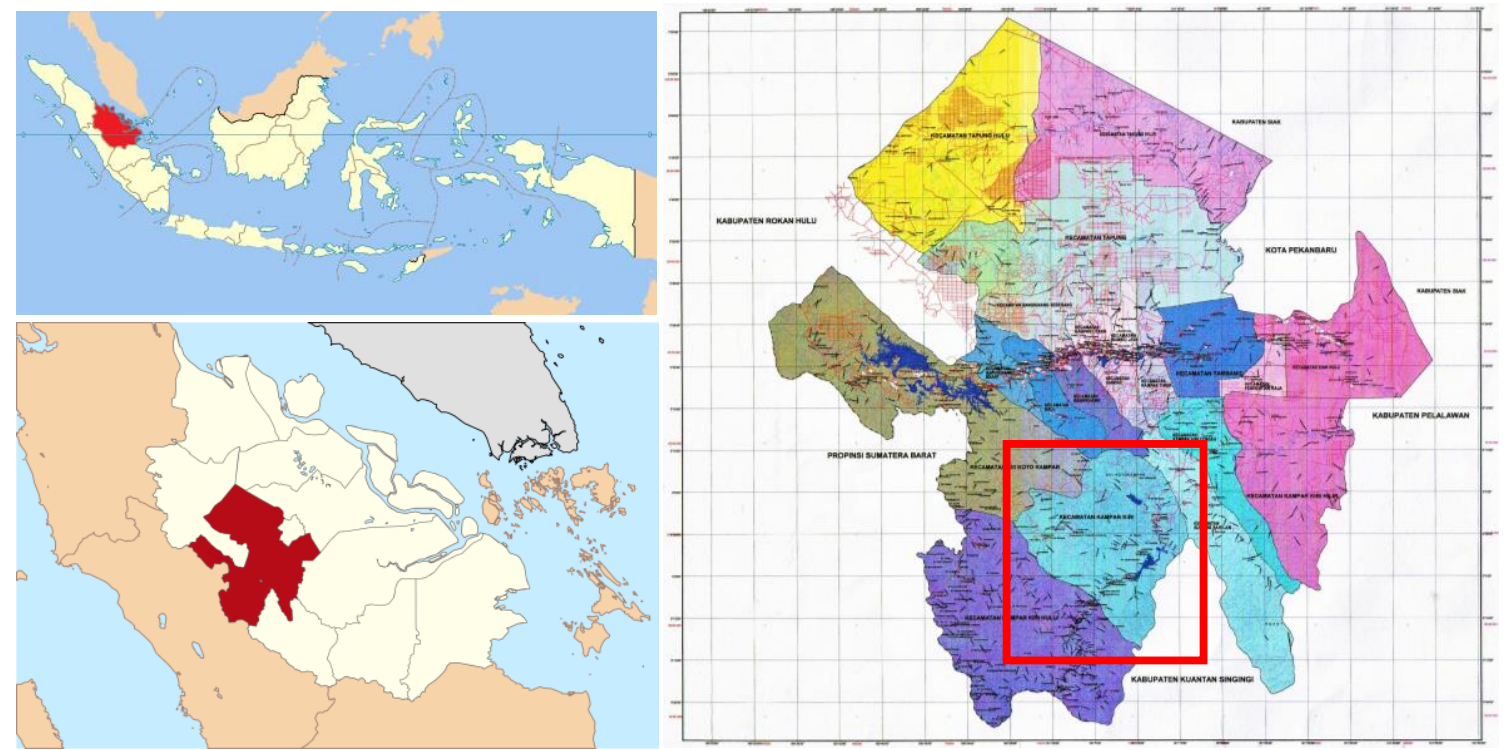

Figure 1. The research location in Kampar Kiri Sub-district (red box), Kampar District, Riau Province, Indonesia 
$N R R=\frac{\text { replacement of young buffalo }}{\text { need of replacement buffalo }} \times 100 \%$

Buffalo replacement $(\%)=\frac{\text { number of adult buffalo }(\%)}{\text { breeding length }(\text { years })}$

Need of replacement buffalo = percent of young buffalo $(\%)$ - buffalo replacement $(\%)$

Number of culling buffalo $=$ buffalo replacement $(\%)$

\section{Estimated output}

The estimated output is analyzed in each population by calculated based on the number of cattle eliminated each year and the number of leftover replacement livestock. The data was obtained from the calculation of data on breeding patterns of bulls and heifers, namely using competition design based on age group:

The estimated output $=$ remains replacement of adult males and females + replacement needs of males and females + male and female culling buffalo.

\section{Population dynamics}

Population dynamics in the estimation of the Kuntu buffalo population data of the last five years with time series analysis of the smallest quadratic method with linear line equation: $\mathrm{Y}=\mathrm{a}+\mathrm{bX}$, where $\mathrm{Y}$ : time-series data, $\mathrm{X}$ : time (year), a: intercept, b: regression coefficient.

\section{Data analysis}

The data in analysis use Microsof Office Excel 2010 computer program to obtain average, standard deviation, and data percentage. For NI values analyzed with three categories namely low (NI,50\%), medium $(50 \%<\mathrm{NI}<80 \%)$ and height (NI>80\%). Value of NRR $<100 \%$ then the needs of replacement livestock are not met, on the contrary, if NRR is $100 \%$ then the needs of replacement livestock are fulfilled (Sumadi 2001)

\section{RESULTS AND DISCUSSION}

\section{Characteristics of buffalo breeders}

The average buffalo breeder in Kuntu is 30-50 years old. Farmer education $80 \%$ graduated from High School (SLTA). The number of dependents of the farmer's family ranges from 3-5 people. The average experience of raising buffalo is 15 years because buffalo breeding is an effort that is done downhill so that the experience of raising buffalo is only obtained from previous ancestors or autodidact. The farmers were able to rear cow well and purpose of cattle rearing was savings. Based on data table 1 , the length of maintenance for buffalo bull is only two years, while the maintenance of buffalo cows is up to 8 years. The average number of cattle raised is $8-15$ heads. Ownership of this livestock is higher than Ongole grade cattle in Kebumen, 1-6 heads per farmer (Rohyan et al. 2016). It was caused due to the constraint of power, so they just reared livestock as a side job (Gunawan et al. 2011). The system on research most location extensive and $6 \%$ was conducted semi-intensively. The buffalo are put in the barn at night while during the day bound to the page. It is fed one to three times a day. Most farmers buffalo eats at night only. The main feed is grass field without concentrate. This can be seen from the body condition of buffaloes after calving to be $60 \pm 8.9 \%$, thin $20 \pm 1.7 \%$, and fat $20 \pm 5.3 \%$ (Table 1).

\section{Reproductive efficiency of Kuntu buffalo}

Reproductive characteristics of Kuntu buffalo are presented in Table 1. The reproductive efficiency value of the Kuntu buffalo was $96.22 \%$, higher than Rohyan et al. (2016) research on Ongole Grade cattle in Kebumen $(91.8 \%)$. The RE value of Kuntu buffalo is relatively low. It was because the age at the first mating of Kuntu buffalo (42 months) was still low and the age of first calving (54 \pm 1.7 months) was still high. According to Rohyan et al. (2016) and D'Occhio et al. (2020) cattle with first mating and first calving age of 27 months will have 100\% RE. This research, first mating and first calving age of buffalo is more than 27 months so that have RE value be less than $100 \%$. This low RE value of Kuntu buffalo indicates that the reproductive performance of the Kuntu buffalo has not been optimally managed. So this condition shows that touch of reproductive technology is needed to optimize the reproductive performance of Kuntu buffaloes. According to Barile (2005), the improvement of reproductive efficiency can be obtained both through improving management systems. Yasir et al. (2020) stated that improved management of the Nili Ravi buffalo in Pakistan could reduce the age at first mating (34.31 months) and age at first calving (47.25 months). Good reproductive efficiency in a female herd is if the calves are born every year (Chaikhun et al. 2012).

The first mating age of Kuntu buffalo was on the age of $42 \pm 0.7$ months. It is lower than Murrah buffalo in India that was 44.74 months (Thiruvenkadan et al. 2015), but it was higher than that of Azhikheli buffalo in Swat Valley Northern Pakistan by Khan et al. (2014) which reached 38.26 months. Differences in seasons, altitude, and rearing system will cause differences in the age at first mating (D'Occhio et al. 2020). The age at first calving of Kuntu buffalo (54 \pm 1.7 months) was greater than the Thai buffalo (47.1 months) (Chaikhun et al. 2012), Brazil Buffalo (41.67 months) (Marques et al. 2020), Murrah buffalo in India (52.62 months) (Thiruvenkadan et al. 2015). This difference age at first calving is influenced by differences in maintenance management and feed management (Rusdin et al. 2020). Bindari et al. (2013) stated that nutritional adequacy will affect changes in livestock reproduction. According to Yasir et al. (2020) age at first, calving can be decreased if age at the first mating faster. The weaning age of Kuntu buffaloes in this research was at age of $1 \pm 2.2$ years (Table 1). It was higher than weaning age of Murrah Buffalo (1.33 \pm 0.02 months) (Bharti et al. 2015). The weaning age will affect the performance of buffalo-cows reproduction (El Debaky et al. 2019). Added by de la CruzCruz et al. (2020) that the age of weaning affects the growth of buffalo calves and first mating after calving. 
Table 1. Reproduction appearance of Kuntu buffalo in Kampar District, Riau, Indonesia

\begin{tabular}{ll}
\hline Variable & \multicolumn{1}{c}{ Average } \\
\hline First mating age (month) & $2.5 \pm 2.5$ \\
Male (sire) (years) & $42 \pm 0.7$ \\
Female (mare) (months) & $2.6 \pm 1.5$ \\
S/C & $54 \pm 1.7$ \\
The age of the first calving (months) & $10.5 \pm 11.2$ \\
Gestation period (months) & $15.3 \pm 2.3$ \\
Calving interval (month) & $1 \pm 2.2$ \\
Weaning age (years) & $6 \pm 5.7$ \\
Postpartum mating (PPM) (month) & $6 \%$ \\
Mating method & $84 \%$ \\
Artificial insemination & \\
Natural mating & 318 \\
The number of partus dam & 343 \\
Male of calf (heads) & 661 \\
Female of calf (heads) & \\
Calving (heads) & $20 \pm 1.7 \%$ \\
The body condition after parturition & $60 \pm 8.9 \%$ \\
Fat & $20 \pm 5.3 \%$ \\
Medium & \\
Thin & $2 \pm 1.5$ \\
Maintenance age limit & $8 \pm 5.8$ \\
Sire (years) & 190 \\
Dam (years) & 1189 \\
Respondent amount & 2746 \\
Dam in the population & 96.22 \\
Sample population & \\
Reproductive efficiency (\%) & \\
\hline
\end{tabular}

Besides that, the habits of farmers in the Kuntu area too prefer to let the calf with the buffalo-cows so the weaning will be longer. The post-partum mating of Kuntu buffalo in this research was $6 \pm 5.7$ months (Table 1). It is longer than was reported by Putra et al. (2017) of Ulakan buffalo in West Sumatra, which reached $5.30 \pm 0.51$ months and Rohyan et al. (2016) research of Ongole grade cows in Kebumen, which reached $4.52 \pm 1.59$ months. The long weaning period in the Kuntu buffalo causes the length of time re-mating after calving (Dhillod et al. 2017). In addition, nutritional factors and the condition of the parents will affect re-mating after calving. Calving interval in this research was $15.3 \pm 2.3$ months. It was lower than CI of Faizabad district buffalo (16.5 months) (Meena et al. 2016) and CI of Pakistan buffalo (Khan et al. 2014). If it is compared to the researcher the other buffalo, calving interval of Kuntu buffalo is much longer than the optimum value expected for buffaloes (Charlini and Sinniah 2015). Therefore effort must be taken to reduce the calving interval through better management both nutrition and breeding. Calving interval in this research was still long, it is caused by post-partum mating of Kuntu buffalo is more than 3 months $(6 \pm 5.7)$, and weaning age of Kuntu buffalo is $1 \pm 2.2$ years.

The gestation period of Kuntu buffalo is $10.5 \pm 11.2$ months. It was lower than Nili-Ravi buffalo in Pakistan under good management and nutrition $(9.68 \pm 0.77$ months $)$ (Yasir et al. 2020). The average gestation period in buffalo ranged from 281 to 334 days (Barile 2005). Gestation period in this research was still too long. It is caused by different management and breed buffalo. Service per conception $(\mathrm{S} / \mathrm{C})$ in this research was $2.6 \pm 1.5$. To produce a Kuntu buffalo pregnancy requires 2.6 times of mating. The average $\mathrm{S} / \mathrm{C}$ in this study was comparatively lower than the value presented by Yasir et al. (2020) in different parity and nutrition buffalo where the S/C was 1.63 . It was lower than what was reported by Putra et al. (2017) on buffalo in the Ulakan reached 1.61 and by Rohyan et al. (2016) on Ongole grade 1.64. These differences are due to differences in management and agro-ecological practices of their respective region (Barile 2005). The mating method applied was natural mating $(84 \%)$ and artificial insemination (6\%) (Table 1). It is due to farmers preferring natural mating it has a higher success rate in producing a pregnancy (Hamid et al. 2016). Singh and Balhara (2016) stated that farmers who do good buffalo management would want artificial insemination on their livestock.

\section{Natural increase}

Natural increase of Kuntu buffalo is $55.59 \%$ (Table 2). These data of NI indicates that the increase of Kuntu buffalo in one year is $55.59 \%$. Based on the data of the birth rate of Kuntu buffalo in Table 1, 50\% of buffalo-cows have had calves. This is because the total birth rate of Kuntu buffalo is higher than the total livestock died. Sumadi et al. (2017) state that natural increase influenced by birth rate and mortality rate. In addition, the condition of Kuntu area is a very suitable environment for the development of buffalo cattle and buffalo cattle are accustomed to the condition of feed in the Kuntu area. Compared to the natural increase of local livestock in other regions in Indonesia, such as buffalo in Ulakan $(23.66 \%)$ (Putra et al. 2017), Ongole grade cattle in Kebumen (44.68\%) (Rohyan et al. 2016), Pasundan cattle in West Java (18.46 \%) (Said et al. 2017) and Kuantan cattle in Taluk Kuantan (5.14\%) (Yendraliza et al. 2020), Kuntu buffalo NI value is higher.

Table 2. Natural increase of Kuntu buffalo in Kampar District, Riau, Indonesia

\begin{tabular}{lc}
\hline \multicolumn{1}{c}{ Variable } & Average \\
\hline Population (head) & 2.746 \\
Dam population (head) & 1.189 \\
Average dam population (\%) & 43.29 \\
calving (heads) & 318 \\
Male (heads) & 26.74 \\
On dam population (\%) & 11.58 \\
On average population (\%) & 343 \\
Female (heads) & 28.85 \\
On dam population (\%) & 12.49 \\
On average population (\%) & \\
Calving rate & 55.59 \\
On dam population (\%) & 24.07 \\
On average population (\%) & 0 \\
Mortality & 0 \\
On dam population (\%) & 0 \\
On average population (\%) & $55.59 \%$ \\
Natural increase &
\end{tabular}


Samberi et al. (2010) stated that the difference in value is due to the high population of mothers who give birth compared to the calf mortality rate. The percentage of natural increase can be increased by reducing the mortality rate for calf and increasing level of conception, so increase of calving rate (El Debaky et al. 2019). According to Khan et al. (2014), a tolerable $5 \%$ calf mortality rate can increase livestock production. Furthermore, Gunawan et al. (2011) also stated in their research on Bali cattle that the mortality rate could be reduced by $0 \%$ with improved maintenance management.

\section{The structure population of Kuntu buffalo}

Kuntu buffalo population structure is dominated by dam livestock (Table 3). In this study, the number of buffalocows is relatively high so it supports breeding programs by community breeders. It was caused for maintenance purposes of the total the breeder aims to get the calf. So that maintenance management still semi-intensive. The breeder does not become main job, only a part-time job. The structure population of the Kuntu buffalo is the same as some other local Indonesian livestock such as; buffalo in Ulakan, West Sumatra (Putra et al. 2017), and Ongole grade cattle in Kebumen (Rohyan et al. 2016), resulting in population structures dominating dams in the population. The average migration of livestock occurs in the production of livestock from Kampar area to outside Kampar. This can be seen from Table 3, only 2 buffalo entered and 270 were removed with a cutting rate of 112 heads. The difference in the percentage of livestock out and enters in the region is an indicator that an area is a livestock producer. Fioretti et al. (2020) state that one of the benchmarks of one area as a livestock producer is the difference in the percentage of cattle that come out more than the incoming livestock. This study showed that the number of buffalo that came out more than the number of buffalo that came in. Based on data Table 3, it is seen that Kampar Kiri can be stated as the source of Kuntu buffalo seedlings.

\section{Net replacement rate and estimated output}

The replacement rate of Kuntu buffalo is $289.6 \%$ for male buffalo and $446.59 \%$ for female buffalo (Table 4 ). This means that the availability of female buffalo for surrogates is 4.46 times that of existing needs and the availability of male buffalo as replacement buffalo is 2.89 times that of existing needs. It means that the Kuntu area had a surplus of the population for male buffalo and female buffalo. It is factor caused is the purpose of the maintenance of buffalo livestock as a nursery. The majority of farmers will sell loose calf after weaning unless the female who has good performance is used as a surrogate mother. Sumadi et al. (2017) state that the value of NRR is used to find out if the number of calf births can cover the needs of surrogate livestock. The NRR value of Kuntu buffalo is greater than NRR buffalo in Ulakan, West Sumatra (Putra et al. 2017) but it was smaller than Pasundan cows in west Java (Said et al. 2017) and Ongole grade in Kebumen (Rohyan et al. 2016). This difference is due to the different conditions of the region and livestock. El Debaky et al. (2019) stated that if the natural increase of buffalo livestock is high, the need for replacement livestock can be fulfilled.

The estimated output value of Kuntu buffalo is $39.24 \%$ (Table 5). It is lower than the value of the Natural increase of Kuntu buffalo $(55.69 \%)$. This value is an indicator that the Kuntu buffalo population is increasing. Sumadi (2017) states that if the estimated value of output is lower than the natural increase, there will be an increase in population. The potential or output of beef cattle in an area is the number of livestock that can be sent or slaughtered from an area without disturbing the balance of the livestock population. The results of the Kuntu buffalo output calculation show that the Kuntu buffalo population has exceeded the need for replacement cattle so that the Kuntu buffalo can be removed, sent, or cut out of the Kuntu area based on the balance between male and female Kuntu buffalo, it can be seen that the distribution of the number of males is balanced with the number of females. Sutarno and Setyawan (2015) stated that animals that are able to adapt to their environment will have superior production and reproduction. The output value of the Kuntu buffalo is higher than Ulakan buffalo in West Sumatra (39.24\% VS 23.66\%) (Putra et al. 2017) and Pasundan cattle (14.58\%) (Said et al.. 2017). But it was lower than Ongole grade cattle $(44.11 \%)$ (Rohyan et al. 2016). These differences in the output because of different birth rates, mortality rates and the number of replacement cattle per year.

Table 3. Structure population of Kuntu buffalo in Kampar District, Riau, Indonesia

\begin{tabular}{|c|c|}
\hline Variable & Total $(\%)$ \\
\hline Population (heads) & 2.746 \\
\hline Livestock Entry & 2 \\
\hline \multicolumn{2}{|l|}{ Mature } \\
\hline Male & 2 \\
\hline Female & 0 \\
\hline \multicolumn{2}{|l|}{ Young } \\
\hline Male & 0 \\
\hline Female & 0 \\
\hline \multicolumn{2}{|l|}{ Calf } \\
\hline Male & 0 \\
\hline Female & 0 \\
\hline Total & 2 \\
\hline Number of livestock entering to population & 1 \\
\hline Cattle out (heads) & 270 \\
\hline \multicolumn{2}{|l|}{ Mature } \\
\hline Male & 89 \\
\hline Female & 23 \\
\hline \multicolumn{2}{|l|}{ Young } \\
\hline Male & 92 \\
\hline Female & 43 \\
\hline \multicolumn{2}{|l|}{ Calf } \\
\hline Male & 10 \\
\hline Female & 13 \\
\hline Total & 270 \\
\hline $\begin{array}{l}\text { The number of livestock that comes out to the } \\
\text { population }(\%)\end{array}$ & 9.83 \\
\hline \multicolumn{2}{|l|}{ Slaughter } \\
\hline \multicolumn{2}{|l|}{ Mature } \\
\hline Male (heads) & 89 \\
\hline Female (heads) & 23 \\
\hline Total slaughter (heads) & 112 \\
\hline $\begin{array}{l}\text { Number of livestock slaughtered against } \\
\text { population }(\%)\end{array}$ & 4.08 \\
\hline
\end{tabular}


Table 4. Net replacement rate of Kuntu buffalo in Kampar District, Riau, Indonesia

\begin{tabular}{lc}
\hline \multicolumn{1}{c}{ Variable } & Total $(\boldsymbol{\%})$ \\
\hline Requirement of buffalo Replacement & \\
Male & 62.50 \\
Female & 132.11 \\
Net Replacement Rate & \\
Male & 289.60 \\
Female & 446.59 \\
\hline
\end{tabular}

Tabel 5. The estimated output of Kuntu buffalo of Kampar District, Riau, Indonesia in 2019

\begin{tabular}{lc}
\hline \multicolumn{1}{c}{ Variable } & Percentage (\%) \\
\hline Remains of replacement stock & \\
Male & 35.75 \\
Female & 119.62 \\
Requirement of buffalo replacement & \\
$\quad$ Male & 62.50 \\
Female & 132.11 \\
Number of culled buffalo & 62.50 \\
Male & 132.11 \\
Female & 39.24 \\
Total Output & \\
\hline
\end{tabular}

\section{Population dynamic}

Kuntu buffalo population from 2014 to 2018 saw an increase of $48 \%$ (Figure 2). Time series analysis equation of Kuntu buffalo population from 2014 to 2018, Y = $467.6 x+938228$. From figure 2, the availability of Kuntu buffalo exceeds the needs of replacement livestock. So that the Kampar area can be used as a source area for Kuntu buffalo seedlings. The result of the analysis of population dynamics showed that the intrinsic growth rate of the buffalo per year are $6.05 \%$. Its population in 2023 can be estimated to be 7.727 heads with a natural increase of $10.73 \%$. the growth rate of Kuntu buffalo lower than Ongole grade in Kebumen (16.7\%) (Rohyan et al. 2016), Ulakan buffalo in West Sumatra (16.53\%) (Putra et al. 2017), and cattle in Moremmana (Fioretti et al. (2020). Although the average growth rate of the Kuntu buffalo shows low, it is still capable to produce seed stock per year and needs a replacement stock fulfilled. Natural increase, livestock migration, and net replacement stock are indicators in analyzing population dynamics in order to predict livestock population output over time.

\section{The morphometric of Kuntu buffalo}

The average body size of an adult Kuntu buffalo differs between a male and a female buffalo (Table 6). The body size of an adult male buffalo is higher than that of a female buffalo. It was caused by the body frame of male buffalo is bigger than female buffalo. The average body size of female and adult Kuntu buffaloes in this study was lower than that of some buffaloes in Asia and Africa (Table 7). The average body length in this study was $116 \pm 3.3 \mathrm{~cm}$ (Table 7), while the average body length recorded was $160.01 \mathrm{~cm}$ in swamp buffaloes Muantai (Komariah et al. 2014), $161.3 \mathrm{~cm}$ in buffaloes Bomban (Nafiu et al. 2015),
$152.23 \mathrm{~cm}$ in buffaloes India (Dhillod et al. 2017) and 122 $\mathrm{cm}$ in Malang, Indonesia (Budiarto and Ciptadi 2018). In Portugal, de Melo et al. (2018) registered a higher average body length of $143.07 \mathrm{~cm}$. It was different from recorded in this study. The average body length in this study indicating that the buffalo studied have small stature and small size. de Melo et al. (2018) stated that the length of the body is less than $130 \mathrm{~cm}$, which is classified as a small size. The average shoulder height was $122.05 \mathrm{~cm}$ and the average hip height was $123.5 \mathrm{~cm}$ in this study. It was lower than Murrah buffaloes in India (Dhillod et al. 2017) and swamp buffalo in Portuguese (de Melo et al. 2018).

The shoulder height and hip height are important parts because related to the respiratory and digestive systems of livestock (de Melo et al. 2018). Dhillod et al. (2017) stated that hip height will affect the working power of livestock. The average chest circumference studied was $175.4 \mathrm{~cm}$ (Table 7), while lower than buffalo in Muantai (Komariah et al. 2014), Malang (Budiarto and Ciptadi 2018), Bombana (Nafiu et al. 2015), and India (Dhillod et al. 2017). This difference is due to the condition of livestock and environment. According to de Melo et al. (2018), a wide chest circumference provides a good digestive ability. The average circumference of scrotum studied was $24.8 \mathrm{~cm}$ (Table 6). It was lower than buffalo Jaffarabadi, Mediterranean and Murrah buffalo $(24.8 \mathrm{~cm}$ VS $32.94 \mathrm{~cm}$, $32.46 \mathrm{~cm}$ and $31.51 \mathrm{~cm}$ ) (Henry et al. 2014). This difference is due to heat stress and changes in environmental temperature in the scrotum, but body size will determine the size of the scrotum.

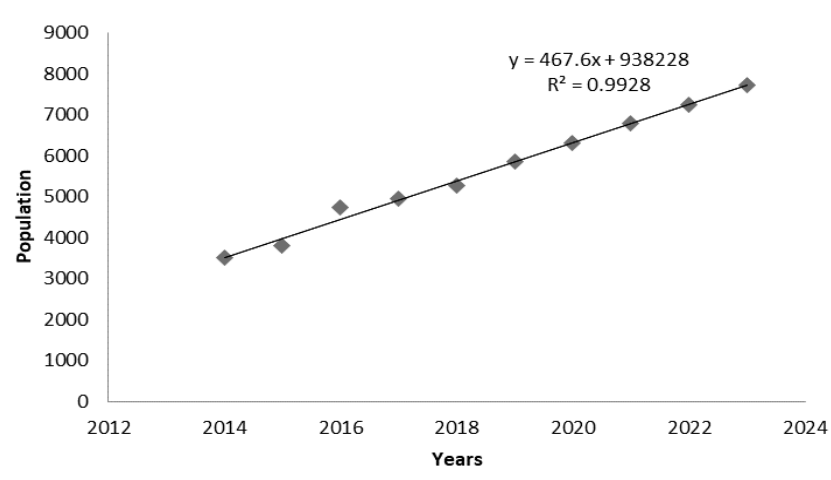

Figure 2. Kuntu buffalo population from 2014-2023

Table 6. The body size of female and male Kuntu buffalo

\begin{tabular}{lc}
\hline Variable & $\begin{array}{c}\text { Average }(\mathbf{c m}) \pm \\
\text { Stdev }\end{array}$ \\
\hline Female (n, 100) & $116 \pm 3.3$ \\
Body length & $119.7 \pm 3.9$ \\
Shoulder height & $121.3 \pm 4.1$ \\
Hip height & $165.9 \pm 4.5$ \\
Chest circumference & \\
Male (n, 100) & $120.4 \pm 1.4$ \\
Body length & $124.4 \pm 1.2$ \\
Shoulder height & $125.7 \pm 1.03$ \\
Hip height & $184.9 \pm 8.09$ \\
Chest circumference & $24.8 \pm 1.35$ \\
Circumference of scrotum &
\end{tabular}


Tabel 7. The average body size of Kuntu buffalo of in Kampar District, Riau, Indonesia and some buffalo in Asia and Africa

\begin{tabular}{|c|c|c|c|c|c|c|c|}
\hline \multirow{2}{*}{ Parameter } & \multicolumn{2}{|c|}{ Kuntu* } & \multirow{2}{*}{ Muntai $^{\mathbf{a}}$} & \multirow{2}{*}{ Bombana $^{b}$} & \multirow{2}{*}{ India $^{c}$} & \multicolumn{2}{|c|}{ Malang ${ }^{d}$} \\
\hline & Male & Female & & & & Male & Female \\
\hline Body length & $120.4 \pm 1.4$ & $116 \pm 3.3$ & 160.01 & 161.3 & 152.23 & 125 & 120 \\
\hline Shoulder height & $124.4 \pm 1.2$ & $119.7 \pm 3.9$ & & 128 & 135.78 & 120 & 115 \\
\hline Hip height & $125.7 \pm 1.03$ & $121.3 \pm 4.1$ & & 126.6 & 226.27 & & \\
\hline Chest circumference & $184.9 \pm 8.09$ & $165.9 \pm 4.5$ & 180.00 & 195 & 214.57 & 190 & 170 \\
\hline Circumference of scrotum & $24.8 \pm 1.35$ & & & & & & \\
\hline
\end{tabular}

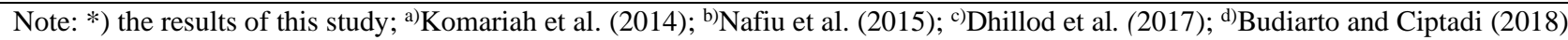

The conclusion of this research is that Kuntu buffalo reproduction is still efficient. The availability of substitute livestock exceeding the need of livestock. The natural increase of Kuntu buffalo population is very high compare with buffalo in Ulakan, West Sumatra. In 2023, the estimated natural increase of Kuntu buffalo of $10.73 \%$. The body size of Kuntu buffalo is classified as small size. Kuntu buffaloes have adapted to the Kuntu area and can be used as the Kuntu buffalo breeding area.

\section{ACKNOWLEDGEMENTS}

This research was funded by the Universitas Islam Negeri Sultan Syarif Kasim Riau, Indonesia under contract number 261/R/2019. The author would like to thank Animal Husbandry Departement Kampar Kiri and special to breeder Kuntu buffalo.

\section{REFERENCES}

Akma GS, Pribadi LW, Yassin M. 2016. Reproductive performance of indigenous Bali Cows in the different farming management and thermal environment of Lombok Island Indonesia. J Agric Vet Sci 9(12): 83-89.

Barile VL. 2005. Improving reproductive efficiency in female buffaloes Livest Prod Sci 92(3): 183-194. DOI: 10.1016/j.livprodsci.2004.06.014

Bindari YR, Shrestha S, Shrestha N, Gaire TN. 2013. Effects of nutrition on reproduction: A Review. Eur Sci J 10 (3): 421-429. DOI: 10.5455/japa.20130531095352.

Bharti PK, Dutt T, Pandey HO, Patel BHM, Mahendran K, Kaswan S, Biswas P, Upadhyay VK. 2015. Effect of weaning age on health of Murrah buffalo calves. Indian J Anim Sci 85 (12): 1370-1374.

Budiarto A, Ciptadi G. 2018. The productivity and natural increase of Swamp buffalo in District Malang. IOP Conf Ser Earth Environ Scie 119 (1): 012037 DOI: 10.1088/1755-1315/119/1/012037.

Chaikhun T, Hengtrakunsin R, De Rensis F, Techakumphu M, Suadsong S. 2012. Reproductive and dairy performances of Thai swamp buffaloes under intensive farm management. Thai J Vet Med 42 (1) 81-85. DOI: $10.1177 / 1040638714534237$

Charlini BC, Sinniah J. 2015. Performance of Murrah, Surti, Nili-Ravi buffaloes and their crosses in the intermediate zone of Sri Lanka. Livest Res Rural Dev 27(3): 1-17.

Chamdi AN. 2005. The characteristics of genetic resources of Bali cattle livestock (Bos-bibos banteng) and alternative conservation patterns Biodiversitas 6 (1): 70-75. DOI: 10.13057/biodiv/d060115. [Indonesian]

Ciptadi G, Budiarto A, Wisaptiningsih U. 2014. Reproductive performance and success of artificial insemination in Indonesian crossbreed goats in research versus smallholder farm. Am-Eurasian J Sustain Agric 8(7):35-38.
Department of Animal Husbandry and Animal Health Riau Province. 2019. Annual Report of the Livestock and Animal Health Service of Riau Province. Department of Animal Husbandry and Animal Health Riau Province, Pekanbaru. [Indonesian]

de la Cruz-Cruz LA, Orozco-Gregorio H, Vargas-Romero JM, HernandezArteaga S, Sanchez-Salcedo JA, Gonzalez-Hernandez M, BallesterosRodea G, Roldan-Santiago P, Bonilla-Jaime H. 2020. Physiological responses in weaned water buffalo calves with different separation strategies. Livest Sci 231 (1): 103892. DOI: 10.1016/j.livsci.2019.103892

de Melo BA, de Melo Nascimento I, dos Santos LTA, de Lima LG, de Araujo FCT, Rios RRS, de Gusmao Couto A, Fraga AB. 2018. Body morphometric measurements in Murrah crossbred buffaloes (Bubalus bubalis). J Appl Anim Res 46 (1): 1307-1312. DOI: 10.1080/09712119.2018.1502669.

Dhillod S, Kar D, Patil CS, Sahu S, Singh N. 2017. Study of the dairy characters of lactating Murrah buffaloes on the basis of body parts measurements. Vet World 10 (1): 17-21. DOI: 10.14202/vetworld.2017.17-21.

D'Occhio MJ, Ghuman SS, Neglia G, della Valle G, Baruselli PS, Zicarelli L, Visintin JA, Sharkar M, Companile G. 2020. Exogenous and endogenous factors in Seasonality of reproduction in Buffalo: A review. Theriogenology 150: 186-192. DOI: 10.1016/j.theriogenology.2020.01.044.

El Debaky HA, Kutchy NA, Ul-Husna A, Indriastuti R, Akhter S, Purwantara B, and Memili E. 2019. Review: Potential of water in world agriculture: Challenges and opportunities. Appl Anim Sci 35: 255-268. DOI: 10.15232/aas.2018-01810.

Fioretti M, Negrini R, Biffani S, Quaglia A, Valentini A, Nardone A. 2020. Demographic structure and population dynamics of Maremmana cattle local breed after 35 years of traditional selection. Livest Sci 232 (4): 1-9. DOI: 10.1016/j.livsci.2019.103903.

Gunawan A, Sari R, Parwoto Y, Uddin M. 2011. Nongenetic factors effect on reproductive performance and preweaning mortality from artificially and naturally bred in Bali Cattle. J Indones Trop Anim Agric 36 (2): 83-90. DOI: 10.14710/jitaa.36.2.83-90.

Hamid MA, Siddiky MNA, Rahman MA, Hossain KM. 2016. Scopes and opportunities of Buffalo farming in Bangladesh: A Review. SAARC J. Agri 14 (2): 63-77. DOI:10.3329/sja.v14i2.31246.

Henry M, Brito MF, Loaiza-echeverri AN,De Oliveira CHS, Gibson AFB, Neves BP, Andrade G de O, Melo IO, Bastianetto E. 2014. Scrotal circumference growth curves of buffalo bulls of different breeds raised in Brazil. Buffalo Bull 32 (1): 439-442.

Kathiravan P, Kataria RS, Mishra BP, Dubey PK, Sadana DK, Joshi BK. 2011. Population structure and phylogeography of Toda buffalo in Nilgiris throw light on possible origin of aboriginal Toda tribe of South India. J Anim Breed Genet 128 (4): 295-304. DOI: 10.1111/j.1439-0388.2011.00921.x.

Khan M, Saleem M, Rahim I, Khan H. 2014. Assessment of morphometric, productive and reproductive characteristics of Azikheli buffalo in Swat valley in Northern Pakistan. Life Sci 11 (12): 1-8.

Marques LC, Matos AS, Costa JS, Silva CS, Camargo Junior RNC, McManus C, Peripolli V, Aroujo CV, Laureano MMM, Sales RL, Marques JRF. 2020. Productive characteristics in dairy buffalo (Bubalus bubalis) in the Eastern Amazon. Arq Bras Med Vet Zootec 72 (3): 947-954. DOI: 10.1590/1678-4162-11288.

Meena BS, Verma HC, Singh A. 2016. Farmers' knowledge on productive and reproductive performances of buffalo under smallholder farming system. Buffalo Bull 35 (1): 101-108. 
Nafiu LO, Saili T, Bain A. 2015. Morphometric portrait of Swamp buffalo in Bombana. In: Proceeding of International Seminar 'Improving Tropical Animal Production for Food Security. Universitas Halu Oleo, Kendari, Southeast Sulawesi, 3-5 November 2015. [Indonesia]

Putra DE, Anwar S, Afriani T. 2017. The estimation potential livestock breeding of buffalo in Ulakan Tapakis District, Padang Pariaman Regency, West Sumatra. J Veteriner 18 (4): 624. DOI: 10.19087/jveteriner.2017.18.4.624. [Indonesian]

Putra DE, Sumadi S, Hartatik T. 2015. The output estimation of bee cattle production in Pesisir Selatan District, West Sumatera Province. J Peternakan Indonesia 17 (2): 105-115. DOI: 10.25077/jpi.17.2.105115.2015. [Indonesian]

Rohyan J, Sutopo, Kurnianto E. 2016. population dynamics on Ongole grade cattle in Kebumen Regency-Central Java. J Indones Trop Anim Agric 41 (4): 224-232. DOI: 10.14710/jitaa.41.4.224-232.

Rusdin M, Solihin DD, Gunawan A, Talib C, Sumantri C. 2020. Genetic variation of eight Indonesian Swamp-buffalo populations based on cytochrome b gene marker. Trop Anim Sci J 43 (1): 1-10. DOI: 10.5398/tasj.2020.43.1.1

Said S, Putra WPB, Anwar S, Agung PP, Yuhani H. 2017. Phenotypic, morphometric characterization and population structure of Pasundan cattle at West Java Indonesia. Biodiversitas 18 (4): 1638-1645. DOI: 10.13057/biodiv/d180444.

Samberi K, Ngadiyono YN, Sumadi. 2010. Estimation of the dynamics of population and productivity of Bali cattle in Kepulauan Yapen Regency, Papua Province. Buletin Peternakan 34 (3): 169-177. DOI: 10.21059/buletinpeternak.v34i3.87. [Indonesian]

Singh I, Balhara AK. 2016. New approaches in buffalo artificial insemination programs with special reference to India
Theriogenology $86 \quad$ (1):

10.1016/j.theriogenology.2016.04.031.

Sumadi. 2001. Estimation of Population Dynamic and Output of Ettawa Crossbreed Goat at Kulon Progo. Buletin Peternakan 25 (4): 161-171. DOI: 10.21059/buletinpeternak.v25i4.1442. [Indonesian]

Sumadi S, Fathoni A, Kusuma SB, Hariyono DNH. 2017. The estimation of natural increase, population dynamics and output of Beff cattle in Klaten Central of Java. In: The 7th International Seminar on Tropical Animal Production, Contribution of Livestock Production on Food Sovereignty in Tropical Countries. Yogyakarta, 12-14 September. [Indonesia]

Sutarno S, Setyawan AD. 2015. Review: Genetic diversity of local and exotic cattle and their crossbreeding impact on the quality of Indonesian cattle. Biodiversitas 16 (2): 327-354. DOI: 10.13057/biodiv/d160230.

Thiruvenkadan AK, Panneerselvam S, Murali N. 2015. Study on ages at first mating and calving of Murrah buffaloes in hot and humid climate of Tamil Nadu, India. Indian J Anim Res 49 (5): 591-594. DOI: 10.18805/ijar.5567.

Yasir MA, Sattar A, Tahir MZ, Akhtar M, Binyameen M, Hammad-urRehman. 2020. Factors affecting reproductive and productive efficiency of Nili rabi buffaloes (Bubalus bubalis) in Punjab, Pakistan. J Anim Plant Sci 30 (3): 568-575. DOI: 10.36899/JAPS.2020.3.0067.

Yendraliza Y, Rodiallah M, Astuti T, Elfawati. 2020. Reproduction status and population dynamic of Kuantan cattle in the Kuantan Singingi Regency. Jurnal Ilmu Ternak dan Veteriner 25 (4): 162. DOI: 10.14334/jitv.v25i4.2541. [Indonesian] 